NJDRS

CDRD

\title{
Technological Intervention in Agriculture Development
}

\author{
Rajan Binayek Pasa
}

PhD Scholar in Education and Rural Development

Lecturer, Central Department of Rural Development, Tribhuvan University

Email for correspondence: rbpshrestha_1942@yahoo.com

\begin{abstract}
Agriculture sector is the single largest employer in the world. Even in Nepal, agriculture sector provides net employment to 60 percent people. In this contexts, this study highlighted importance of technological intervention in agriculture development. However, focus was given to assess socio-economic situations of the farmers and impact of modern technological interventions. In so doing, the survey was conducted in Lele Village of Godavari Municipality. The respondents were randomly selected 152 sample households using modern/traditional agriculture technologies. The necessary primary data collected through households' survey questionnaires, observation and informal communications whereas secondary data generated from published/unpublished books, journals, inter/national reports and local level profiles. The study found that modern technological intervention has been fostering commercial farming activities in Lele village and increased family income, creating self-employment and generating rural economy in particular and supporting to the rural development process in general. Further, local development stakeholders need to provide technical/financial supports to the farmers for mounting intervention of modern agriculture technology in Lele village. The finding of the study has possibility to replicate in similar situation throughout the country.
\end{abstract}

Key words: Traditional/modern technology, intervention and agriculture development. Setting the Scene

Globally, agriculture sector is the single largest employer in the world. The sector has been providing livelihoods for more than 40 percent of global population and creating income and job options to the poor rural households (United Nations [UN], 2015). However, globally 836 million people are still living with extreme poverty and the vast majorities of the world's 12.9 percent hungers or undernourished people are living in developing countries (UN, 2015). No doubt, the situation is becoming thundering problems for family self sufficiency and rural development. Owing to that the ideas of agriculture development or improving productivity and resilience of subsistence agricultural practices have been prioritized globally. The case studies of Tanzania, China, Thailand, South Korea and Japan shows the diverse functions that agriculture had played for rural and national development and its potential for improving the well being of rural populations (Organization for Economic Cooperation and Development [OECD], 2015). Further, agriculture is still an important source of work, with 1.34 billion people worldwide working in or seeking work in agriculture (UN, 2015). Most of this work is on family farms. Some 70-80 percent of the world's agricultural land is managed by around 500 million family farms whose workers, mostly family, produce more than 80 percent of the world's food (United Nations Development Programme [UNDP], 2015). 
Locally, out of total population $(26,494,504)$, more than 80 percent people are still living in rural areas with rampant poverty and hunger and applying subsistence farming as livelihood strategy (Central Bureau of Statistics [CBS], 2012). Majorities of the rural households have little or no access to primary health care, education, safe drinking water, sanitation or other basic services (International Fund for Agricultural Development [IFAD], 2015). And the proposed SDG 1 targets for 2030 are to reduce extreme poverty to less than five percent, reduce poverty gap to 2.8 percent, raise per capita income to US\$ 2,500 and raise social protection budget to 15 percent of total budget (NPC, 2017). In these contexts, it is necessary to make agriculture sector competent to take comparative advantage through its commercialization and diversification. Nepal, predominantly an agrarian country, has a huge potentiality of agriculture development in which agriculture sector provides net employment to 60 percent people (Agriculture Development Strategy [ADS], 2012). Thus, from the perspectives of global/local contexts, it is inevitable to mount intervention of modern agriculture technology for agriculture development.

\section{The Background}

Technology generally means the well combination of energy, tools, knowledge and skills whereas technological intervention means adaptation of modern agriculture technology to improve productivity. The adaptation modern agriculture technology such as farming tools, improved varieties of seeds and inorganic fertilizers can foster agriculture development. Interventions of modern agricultural technology become long run equilibrium when the farmer has full information about the new technology and it is potential (Feder \& Zibleman, 1985). Sociologists have indentified many sociological factors such as; characteristics of rural countries, the personal and situational characters of farmers and their families, such as farmers' age, educational level and their perceptions on agricultural transformation (Hotter, 1958).

Agriculture transformation is possible with intervention of modern agriculture technology that can be measured by the aggregate level of use of a specific technology within in a given geographic area or given population (Feder, 1985, p. 63). The empirical finding indicates that the relationship between the intervention of modern agriculture technology and poverty reduction has been perceived to be positive (Bellon et al., 2006). Productivity-improving technologies reduce poverty by reducing food prices, facilitating the growth of nonfarm sectors and by stimulating the transition from low productivity subsistence agriculture to a high productivity agro-industrial economy (Just \& Zilberman, 1988). The potential for poverty reduction through reduced food prices, growth in the nonfarm sector and agricultural commercialization depends to a large extent on the magnitude of productivity gains in agriculture.

Theoretically, agriculture transformation theory of Schultz (1979) emphasized that key to agricultural transformation lies in emphasizing technological change in agriculture. He argued that peasants are poor but efficient, they can bring about productivity increases and improvements provided they are given access to modern technologies. Therefore according to Schultz, government need to accelerate output growth through technological intervention and raising domestic demand for agriculture output for making agriculture as tool for employment generation strategy (Author \& Lekhi, 2008). Likewise, technology transfer theory claimed that technology transfer is the reciprocal process that involves not only the product but also a set of practices. Technology transfer is widely affected by the culture, which dictates a particular way of 
constructing, interpreting, and communicating meaning of technology, about what constitutes the knowledge about technology among government, experts, technicians and ordinary users (Cummings, 1990). However, according to Rogers \& Shoemakers (1971), the degree of adaption or rejection of technology depends upon the individuals' passes through five steps; awareness stage, interest stage, evaluation stage, trial stage and adoption stage. Similarly, agricultural modernization theory seeks to transform the land system, relations of production, promote the transformation of agricultural industrial organization and promoting the spontaneous revolution in agricultural production (Tang, 2011). More so, there must be interdependent relationship between agricultural organization, transformation in agricultural industrial organization and agricultural technology for agriculture modernization in any country.

Reflecting upon such theoretical propositions, developed countries are applying modern agriculture technology. They are producing crop a lot in a limited plot of fields and with limited manpower for mass grain production with limited production components whereas least/developing countries are still suffering from large amount of food deficits. Nepalese economy is still dominated by agriculture sector and agro-based industries. More than 80 percent people depend on agriculture (i.e. 4.2 million) and agriculture provides net employment to 60 percent people and the bulk of the country's export earnings (WB, 2010). However, food items and animal products import during the first eight months of current fiscal year 2015/16 is estimated to fall by 13.9 percent to Rs. 435.8 billion as compared to that of previous fiscal year (MoF, 2016). In fiscal year 2015/16, Nepal expensed NRs. 39 billion only for importing good grains from different countries (Trade and Export Promotion Centre [TEPC], 2016).

The history of economic development in Nepal also indicated that agricultural productivity has been major source of improvements of rural livelihoods. Adoption of modern technology is possible when the input and output markets are functioning well in all agroecological zones in Nepal (Jacoby, 1998). The adoption of technologies in terms of using tradable inputs, such as improved varieties of seeds and inorganic fertilizers in particular, is regarded as an indication of the agricultural change towards the commercialization path. Development of improved technologies like; improved seeds, fertilizer, pesticides, farming techniques and use of agricultural tools and instruments and trained human resource have contributed largely to the agriculture production (MoF, 2016). Even though, most of the farmers in Nepal are still using traditional and indigenous technology at agriculture. That traditional and indigenous technology is not able to produce much food. There are varies factors affecting farmer to use new technology. Illiteracy, financial support, awareness, availability are some key factors among them (IRIN, 2013). The income benefits from the technologies were widespread, and this contributed to greater impacts on the non-farm economy via demand linkages. Increased productivity also reduced the foreign exchange burden of food imports in food-importing countries and contributed to increased foreign exchange earnings through diversification into exportable commodities (ADB, 2004).

Nepal is now facing central challenge for shifting traditional subsistence farming into modern farming and adaptation of traditional technology into modern technology. In such a context, agriculture is the main source of food, income and employment for the majority of population, particularly in rural areas. However, in many low-income countries, farmers are constrained with access to various resources in order to adopt new technologies resulting from high transaction costs and price volatility (Yesuf \& Kohlin, 2008). Most of the farmers in Nepal

Nepalese Journal of Development and Rural Studies, 14 (1\&2), 2017 
are still using traditional and indigenous technology and suffering from food deficit. Therefore, this study tried to analyze intervention of modern agriculture technology around Lalitpur District with the references of agriculture development policies and practices.

\section{Agriculture Development Policies and Practices}

In Nepal, agricultural development is widely acknowledged as a critical component in a strategy to boost livelihoods of the rural people. It is often discussed at the policy level that the commercialization of agriculture, which mostly relied on imported agricultural technologies, including improved seeds, chemical fertilizers and pesticides enhanced productivity growth. Several policies were formulated and implemented in order to boost this sector. The country has initiated the economic liberalization programs since mid-1980s, but bold measures of economic restructuring took place after the commencement of trade reform policy in 1992, that included tariff cuts, abolition of import license auction, subsidies' removal, improvement of export incentives, deregulation of foreign investment and reformulation of the tax sys-tem (MOC, 1992). However, those policies have not increased output of food grain at the same rate as population growth.

Agricultural perspective plan (APP) (1997-2017) is first long term vision to increase agricultural productivity that stresses priority inputs (i.e. irrigation. rural roads, fertilizer and agricultural technology) to achieve priority outputs (i.e. increased production of fruits, vegetables, livestock, forestry and promotion of agri-business). The APP was designed to promote about 5 percent annual agricultural growth in order to achieve poverty alleviation goals set by the Government. It has emphasized applying modern technology as major priority input in farming system of the country. Rapid growth in agriculture has been emphasized to reduce poverty, which was the single most important objective of the current Tenth Five-Year Plan of Nepal (NPC, 2002). The Tenth Plan set the following objectives for the sector: (i) reduce poverty by increasing production, productivity, and income from agriculture, and contribute to food and nutritional security; (ii) contribute to sustainable production and growth by adaptive research and development of technology to be used in agriculture, while protecting and using agro-biodiversity and balance in the environment by reducing pollution from the use of external inputs; and (iii) develop the internal market and promote export opportunities by promoting agro-based industries and enterprises with the participation of cooperatives and private sector.

Since many years there has been a surge of interest and debate in public forum about the need to increase public sector investment in agriculture, and policy reform for agricultural development in Nepal. Recently, Government of Nepal has prepared agriculture development strategy (ADS), a 20-year strategy paper for agriculture sector development jointly collaborating with technical assistance team, financial support mainly from ADB, co-financed by IFAD and contributions by EU, FAO, SDC, and JICA. ADS aimed to allocate significant budget in agriculture sectors, intended to implement various capacity building, rural infrastructure development, research and agriculture development projects and large scale private investment in transfer modern technologies (MOA, 2012). Transformation of agriculture sectors tourism industries and small and medium sizes rural industries in fourteenth plan (NPC, 2016). Out of twenty two devolved power/jurisdictions; function of local cooperatives, management of local markets, agriculture roads and irrigation facilities, extension of agriculture productions, livestock 
health and cooperative and small electricity and alternative energy projects are directly linked with agriculture development in local levels (Constitution, 2015).

In practice, Nepal is predominantly an agrarian economy. It is the main source of livelihood of the Nepalese people. Still 74 percent of the people are dependent on agriculture sector. This sector contributes for about 35.0 percent of the GDP. Nepalese economy has undergone a gradual structural shift in the recent years. The share of service sector has increased gradually and reached nearly half of the GDP. The share of service sector has increased gradually and reached nearly half of the GDP. The trend data from 2002-2016 indicate that in an average agriculture sector has been contributed 4.02 percent share in GDP. The lowest 2.8 percent share on was held in 2006/07 and highest 5.8 percent share was held in 2007/08. After 2011 the sector has contributed more than 4.5 percent share on GDP (Economic Survey, 2011/12 \& 2015/16, MoF).

\section{Research Objectives}

- To assess social and economic situations of the selected households.

- To examine interventions of traditional/modern agriculture technologies.

- To analyze impacts of modern technological intervention in agriculture development.

\section{Research Design}

Research design helps to construct appropriate method in order to address research objectives that are established to examine social phenomena (Scotland, 2012). Owing to that, this study followed quantitative research approach to explain researching issues/objectives. Under quantitative approach, I applied survey method, a numerical description of relevant aspects of a study population. Survey method hence, collect data from specifically defined group of individuals (respondents) by asking number of questions and analyze collected data (Baker, 1994). Within various forms of survey, I applied trend survey that has covered single subject intervention of modern agriculture technology in agriculture development. For that purpose, I selected Lele village lies in Godavari Municipality of Lalitpur District as a field of the study. According to Census (2011), there were total 1822 households with total 8411 population (4032 male and 4379 female) in Lele. Out of total households, 242 household applying modern technologies were regarded as sample population of the study. And out of sample population, 152 households were selected as sample number which is calculated by sample size determination formula (Krejcie \& Morgan, 1970). Survey questionnaire and observation techniques were applied for collecting data from randomly selected households around Lele village.

\section{The Findings: Socio-economic Situations of the Respondents}

Right from the beginning, farmers of Lele village have been performing agriculture/animal husbandry based livelihood. However, after constructed Rajkulo in Nakhhu Khola around late 19th century, farmer started supply their surplus crops. But after intervention of modern agriculture technologies, farmers started commercial vegetable farming/animal husbandry that is becoming regular sources of family earning and rural economy. Farmers are supplying milk, orange, plum, pears, lapssi, kiwi, lemon, papaya and vegetables such as; potato, tomato, cabbage, cauliflower, broccoli, spinach, simsag, garlic, ginger in urban centers. During informal communication my participant shared that, Dairy Development Corporation has been started milk processing center since 1975 and Kathmandu Dairy also started milk processing center last year. Those centers collect per day more than 50000 liter milk from southern villages of Lalitpur and 
Makawanpur Districts before supplying in capital city (J. K. Bajgain, personal communication, 12th October 12, 2016).

These scenarios indicate quality socio-economic situations of the selected households. However, in this section, socio-economic situations of the farmers, tried to examine though different variables; occupation, family size, land holding, age, sex, religion, education, annual income and expenditure of the respondents. Occupational status of the individuals determines the level of income. Most of the villagers from the study area are involving in commercial farming; local business including supply of agro based products as well as government and private jobs. The data shows that 32.23 percent of the respondents' family members are involving in government job and 30.26 percent in private job including foreign employment. Similarly, 19.73 percent of the respondents' family members are involving in business sector and 17.78 percent in wage labors respectively.

Agriculture based livelihood and joint family system are unique features of rural areas. Even in Lele village, majorities $(68.42 \%)$ of the respondents are living in joint family system and least $(31.57 \%)$ of the respondents are living in nuclear family system. Though, farmers living in nuclear family system are also involving in commercial farming and adopting modern agriculture for working efficiency. Land is the main source of agricultural production in which most (39.47\%) of the respondents have 5-14 Ropani land and equal 20.39 percent respondents have less than 5 Ropani and more than 25 Ropani land. It seems that farmers of Lele village have limited plot of agricultural land but intervention of modern agriculture technology helped to increase productivity and utilization of land resources. Some of the landlords are also providing their lease hold land to the migrated and local farmers in contract basis.

Age is another variable to analyze commercial farming practices. No doubt, energetic and productive youth farmers can transform traditional farming into commercial one. The study shows that most (41.44\%) of the respondent' age lies in between $35-44$ years and least $(28.28 \%$ ) of the respondents' age found more than forty five years. Similarly, 31.57 percent respondents' age lies between 25-34 years. Data highlights that all of the farmers are found from active age group. Similarly, majorities (95.39\%) respondents happily shared that female and children are equally working in farming activities and supporting family livelihood. Likewise, it is clear that religious and ethnic values and norms guide the cultural and economic activities of particular community. Out of total sample respondents, Kshetri, Tamang, Brahmin, Newar and Dalits found 48 percent, 30 percent, 25 percent, 16 percent and 10 percent respectively. The data confirm that Lele village is rich in cultural diversity and social integrity as they are still practicing Perma (i.e. labour exchange system in farming) and living with mutual relationships or bridging social capital. Hindu religion is dominant in the village and majorities of them are rearing cow, a national animal and symbol of Laxmi. Hindu people worship cow and use cow milk/urine also with religious purpose. Kshetri and Brahmin ethnics are rearing buffalo, cow and goats except pig as Hindu culture does not allow keeping pig as domestic animal. But Janjati and Dalits ethnics are also rearing pigs.

Education is another variable to analyze commercial farming practices as educated farmers use modern agriculture tools and technologies. Data demonstrate that 24 respondents were illiterate but having various informal knowledge and experiences related to commercial farming. Similarly, 56 respondents passed at least lower secondary, 39 respondents completed secondary level education and remaining 33 respondents passed higher education. Educational status of the 
farmers has played a key role to adapt modern agriculture technology. Income and expenditure are measuring variables while analyzing living standard of the rural people. Higher income/expenditure indicates higher status of family and rural economy as well as proper mobilization of financial resources. The data illustrates that in average most $(65.13 \%)$ of the respondents earn between 30,000-45,000 NRs monthly and least (20.39\%) of the respondents earn more than 45,000 NRs monthly. Similarly, data depicts that most (30.26\%) of the respondents expense in between 25,000-35,000 NRs. During informal interaction, my participant shared that most of the households are saving at least 10,000 NRs monthly as their members are involving in government/private job, foreign job, commercial vegetable/crop farming, animal husbandry, working in rural industries as well as daily wages (M. Timilsana, personal communication, 14th October, 2016).

\section{Intervention of Traditional/Modern Agriculture Technology}

Modern farming practices depend upon adaption of modern tools and technologies. During my observation and conservation, I understood, Good neighbor international nongovernment organization has been provided agriculture/community development related training programs to the local farmers of Lele and its neighboring villages. And there was a demonstration filed of modern agriculture technologies nearby office (Observation, 10th October, 2016: 11AM to 1PM). Even during interaction, my participant happily shared that, there are 2 agriculture collection and distribution centers in the village. Local business person then supply those products in Chapagaun collection center then other channel finally supply in Balkhu, Lagankhel and Kalimati vegetable markets (G. Thapa, personal communication, 10th October, 2016). The situations indicate that intervention of modern agriculture technology in Lele village became possible with the continuous efforts of government and non-government sectors.

In these connection, this section tried to analyze intervention of traditional/modern agriculture technology through the variables; soil preparation, harvesting crops, using fertilizer and pesticide, practicing traditional/modern technologies, major sources of diffusing technological ideas and interest formation of the farmers. Regarding soil preparation, data shows that majorities $(72.36 \%)$ of the respondents are applying modern agriculture tools (i.e. modern hoe, tractor, power trailer) for soil preparation and least $(27.64 \%)$ of the respondents are still using traditional tools (i.e Kuto-Kodali) to same purpose. The situation shows that farmers are changing the way of agricultural practices because of raising level of awareness and institutional support. Similarly, majorities $(61.18 \%)$ of the respondents are using both traditional/modern tools during crop harvesting and least $(39.47 \%)$ of the respondents are using only modern tools for same purpose (see in table 1).

Table 1. Different Technologies for Harvesting Crops/Vegetables

\begin{tabular}{|c|c|c|}
\hline Traditional/Modern Tools & Functions & Households \\
\hline - $\quad$ Sickles & Cutting plant of crops & 152 \\
\hline - Cart & Carrying crop up to store & 36 \\
\hline - Hand tools to separate crop from plant & Purifying crops & 152 \\
\hline - Labor force & Collect products & 78 \\
\hline - Threshing machine on hire & Purifying crops & 112 \\
\hline - Cutting machine & Cutting grass and hay & 86 \\
\hline - $\quad$ Power trailer on hire & Soil preparation & 142 \\
\hline
\end{tabular}

(Field Survey, 2016).

Nepalese Journal of Development and Rural Studies, 14 (1\&2), 2017 
The above table reflects the information on using various types of traditional and modern technologies. The data shows that majorities of the respondents are using both traditional and modern agriculture tools and technologies while involving in farming activities. Utilizing new technology helped to reduce time, cost and risks of damaging harvesting crops. There are several technologies using in farming practice in the context of Nepal. It was/is due to higher level of practicing subsistence farming system still farmer are using various traditional and modern technology for their agricultural production (see in table 2).

Table 2. Different Technologies Using for Caring the Crops/Vegetables

\begin{tabular}{|c|c|c|}
\hline Traditional/Modern Technology & Functions & HHs \\
\hline - $\quad$ Cannel irrigation & Irrigation to whole land & 112 \\
\hline - Compost fertilizer & Utilizing compost manure & 152 \\
\hline - $\quad$ Herbal pesticide & Utilize herbs and urine of cattle's to crops & 98 \\
\hline - $\quad$ Removing grass & Remove by hand & 152 \\
\hline - Chemical pesticide & Spray chemical on crops & 132 \\
\hline - Chemical fertilizer & Mix chemical fertilizer on soil & 138 \\
\hline - $\quad$ Pipe irrigation (Drip, sprinkle) & Irrigate only plant through water pipe & 65 \\
\hline - Tunnel vegetable farming & Vegetable production in plastic tunnels & 45 \\
\hline - High value animal husbandry & Cow, buffalo and goats & 122 \\
\hline
\end{tabular}

(Field Survey, 2016).

The data from above table indicates that majorities of the respondents are using both modern and traditional tools and technologies. One of the factors for using modern agriculture technology is easy accessibility as Lele village is located just 12 kilometer southern far from capital city. Literature also says that adoption of modern technology is possible when the input and output markets are functioning well in all agro-ecological zones in Nepal (Jacoby, 1998). Similarly, chemical fertilizer and pesticides is using by majorities (90.18\%) of respondents whereas 64.47 percent respondents are still using organic pesticides against plant diseases and infection. Likewise, for increasing productivity, farmers are gaining knowledge on modern agriculture technologies through various sources of information (see in table 3 ).

Table 3. Source of Knowledge Gaining on Modern Technology

\begin{tabular}{lcc}
\hline Types of Media & Number of Sample Households & Percent of Households \\
\hline FM Radio & 152 & 100.0 \\
Television & 152 & 100.0 \\
Exposure visits & 102 & 67.10 \\
Market and fair & 114 & 75.00 \\
Neighbor & 152 & 100.0 \\
Newspaper & 112 & 73.68 \\
Others & 48 & 31.57 \\
\hline
\end{tabular}

(Field Survey, 2016).

The above table illustrates the information on various sources of knowledge gaining for adaption of modern technologies. From the data it is found that majorities of the respondents are gaining knowledge on modern technologies equally from audio-visuals, exposure visits, trade fairs, newspapers and neighbors. Likewise, majorities $(60.52 \%)$ of the respondents have a higher level of interest for adopting modern tools and methods whereas remaining 39.47 percent of the respondents are still interested to apply both modern and traditional tools and methods for agricultural activities. Fertilizer is one of the factor increase agricultural product. Even though most of the farmers expressed they adapted modern agriculture technology after evaluating 
working efficiency and productivity. Technology transfer theory also claimed that degree of technology depends upon the individuals' passes through five steps (e. g. awareness, interest, evaluation, trial and adoption stages) (Rogers \& Shoemakers, 1971, p.68).

\section{Intervention of Modern Agriculture Technology: Status and Impact}

As Shultz argued peasants are poor but efficient, they can bring about productivity increases and improvements provided they are given access to modern technologies (Author \& Lekhi, 2008), even due to intervention of modern agriculture technology Dalits and Janjati ethnic are also transforming their family livelihood and community well-being in Lelel village. During my interaction, my participant shared that, Dalits are involving in government/private jobs, commercial farming, and wage labour. Some educated youth are also working in abroad. Parents are investing in child education. Daily life, livelihood and socio-economic status of Dalits have been improved. All these charges have been occurred because of surplus production or commercial farming (R. B. Narakoti, personal communication, 14th October, 2016). The empirical finding also claimed that the relationship between the adoption of new technology and poverty reduction has been perceived to be positive (Bellon et al., 2006).

Hence, in this section, status of modern technological intervention has been analyzed through the variables; types and availability of modern technology, diffusion process and motivation to use modern technology and institutional support. In this response, the study found that majorities (87.5\%) respondents are using both methodological and mechanical based modern technology such as; new ideas and productive knowledge related to agricultural transformation, new variety of hybrid seeds, fertilizer and pesticides as well as modern agriculture tools and methods that can increase production, working efficiency and time consuming to the local farmers. However, 12.5 percent households are using methodological based modern technologies such as; new ideas, knowledge, and modern inputs.

Utilization of new technology depends on accessibility and availability. The data explain that majorities $(87.5 \%)$ of the respondents shared that modern agriculture tools and inputs are available in local hinterland and urban centers. In case of diffusion of modern technology, farmers are acquiring knowledge on agriculture from exposure visits and training programs. Role model farmers are also sharing their knowledge and skills to the local farmers and suggesting them to adapt modern technology. Similarly, 30.26 percent respondents argued that local government bodies need to diffuse any kind of modern methods and tools for local farmers. Motivation also plays vital role to adapt modern technology. The data shows that 87.5 percent respondents are motivating by the demonstration effects and exposure visits. Likewise, 12.5 percent respondents found self motivated to use modern agricultural technology. Most of the farmers are getting technical/financial supports from government and I/NGOs sectors.

In order to examine impact of modern technological intervention some of the variables; comparative annual income, outcomes of using modern technology, drawbacks of modern tools and technologies, major problems for using modern technology and impact of modern technology have been assessed. In this response, the data illustrate that majorities (87.5\%) of the respondents are using modern technology because of working efficiency and higher productivity. As the data indicate that using modern technology is benefited to farmers in various ways, it is essential to foster modern technological intervention on agriculture development that can improve house hold 
income and generate rural economy. The level of family income has been significantly increased in Lele village after intervention of modern technology in farming system (see in table 4).

Table 4. Income Analysis Before and After Using Modern Agriculture Technology (MAT)

\begin{tabular}{lcc}
\hline Income & HHs Before Using MAT & HHs After Using MAT \\
\hline$<99,000$ & 31 & 9 \\
$100,000-1,49,000$ & 46 & 17 \\
$1,50,000-1,99,000$ & 32 & 22 \\
$2,00,000-2,49,000$ & 17 & 27 \\
$2,50,000-2,99,000$ & 14 & 32 \\
$>3,00,000$ & 12 & 45 \\
Total & $\mathbf{1 5 2}$ & $\mathbf{1 5 2}$ \\
\hline
\end{tabular}

(Field Survey, 2016).

The above table shows the information on comparative family income status of the sample respondents. Data indicate that respondents who earn below 90,000 are decreased by 31 households to only 9 households and who earn between 2, 50,000 to 2, 99,000 increased from 14 households to 32 households and who earn $>3,00,000$ also mounted from 12 households to 45 households respectively. The data indicate that significant increase in family earning became possible with the intervention of modern technology (e.g. both mechanical and methodological) in farming system. Majorities of the respondents also argued that commercial farming activities are major outcomes of modern technological intervention in the village. Hence, it is essential to convince and support them who are still practicing subsistence farming system around Lele village. More so, there must be interdependent relationship between agricultural organization, transformation in agricultural industrial organization and agricultural technology (Tang, 2011) for modernization of agriculture and fostering rural industries in Lele village.

Using modern technology also has some possible drawbacks. Most 112 respondents argue that it is expensive to use and least 18 respondents reflect that they are facing technical difficulties while using. Government mechanism thus needs to mobilize technical manpower in the village level for addressing such problems. Regarding impact of the modern technologies, most of the respondents argued that most of the technologies are geographically feasible, socio-culturally acceptable but not yet economically viable. Even though, majorities 112 respondents reflected that modern technological intervention brings transformation in subsistence farming and also creating self-employment. Hence, local government must implement devolved power/jurisdictions related to local cooperatives, management of local markets, agriculture roads and irrigation facilities, livestock health and cooperatives, extension of agriculture productions and rural energy and technology for agriculture development around Lele village (Constitution, 2015).

\section{Conclusion}

Modern technological interventions have been fostering agriculture development practices in Lele village. Commercial vegetable farming and animal husbandry practices have been becoming potent income sources of the local people. Farmers are adapting modern agriculture technologies and that has increased their productivity and profitability. The livelihood of the farmers also has been improving satisfactorily. Situating nearer from capital city and Langankhel urban center, the village is connected with good networking of road infrastructures and marketing facilities. Farmers have good accessibility with service delivery mechanism related to commercial farming and modern agriculture technologies. However local farmers are also applying traditional technologies. Government institutions (e.g. district agriculture development office, department of agriculture and agriculture service center) and non government institutions are offering skill 
development trainings and providing information on modern agriculture technologies (mechanical and methodological) to the role model farmers. Farmers adopting modern agriculture technology are successfully producing high quantity of farm products. They are getting opportunities to generate comparatively more income than those who are still adopting traditional technology. However, still agro based food processing centers and rural enterprises are not yet established in the village that could create employment opportunities to the local youths and generate rural economy in productive manner.

\section{References}

Agriculture Perspective Plan (APP). (1995). Nepal 20 Years' Agriculture Perspective Plan. Kathmandu: Agricultural Projects Services Centre and John Mellor Associates, Inc.

Agriculture Development Strategy (ADS). (2012). Preparation of the Agriculture Development Strategy (ADS), Assessment Report.

Asian Development Bank (ADB). (2004). Improving technical education and vocational training strategies for Asia. Manila: Asian Development Bank.

Baker, T. L. (1994). Doing social research. United States: McGraw-Hill, Inc.

Bellon, M. R., M. Adato, J. Becerril \& D. Mindek (2006). "Poor Farmers Perceived Benefits from Different Types of Maize Germplasm: The Case of Creolization in Lowland Tropical Mexico". World Development, 34 (1), 113-129.

Central Bureau of Statistics (CBS). (2012). National Census of Agricultural Raw Statistical Estimate. Central Statistics Department, Thapathali, Kathmandu, Nepal.

Cummings, R. W. (1990). Agricultural technology management. In R. G. Echeverria (Ed.), Methods for Diagnosing Research System Constraints and Assessing the Impact of Agricultural Research, (pp.15-30).The Hague, Netherlands; International Service for National Agricultural Research.

Constitution of Nepal (2015). Constitution of Nepal 2072 BS. Kathmandu: Lumbini Pustak Pasal.

Feder, G., Just, R. E. \& Ziblerman, D. (1985). Adoption of Agricultural Innovation in Developing countries: A survey of Economic Development and Cultural change. New York.

Hotter, C. R. (1958). Farmers Reaction of New Practices East Lansing, Michigan Agri, Exp. Sta. Tech, Bal, USA.

International Fund for Agricultural Development (IFAD) (2015). Building a poverty-free world; enabling poor rural people to overcome poverty in Nepal.

IRIN (2013). Analysis: The trouble with Nepal's agriculture. Published on Jan 23rd, 2013. Retrieved from http:/www.irinnews.org/report/97321/analysis-the-trouble-with-nepal-sagriculture

Jacoby, H. G. (1998). Shadow Wages and Peasant Family Labour Supply: An Econometric Decisions: An Empirical Analysis. Environment for Development Discussion Paper Series (EfD DP) 08-04. Kathmandu, Nepal.

Just, R. E. \& D. Zilberman (1988). "The Effects of Agricultural Development Policies on Income Distribution and Technological Change in Agriculture". Journal of Development Economics, 28 (2), 193-216.

Krejcie \& Morgan, (1970). Determining sample size for research activities. Educational and Psychological Measurement, (30), 607-610. 
Lekhi, R. K. (2008). The economics of development and planning (11th ed.). New Delhi: Kalyani Publishers.

Ministry of Agriculture (MoA). (2012). Twenty Years Agriculture Development Strategy (201434). Author.

Ministry of Finance (MoF). (2011). Economic Survey 2010/011. Kathmandu: Author.

Ministry of Finance (MoF). (2016). Economic Survey: Fiscal Year 2015/16.Kathmandu: Author.

Ministry of Industry (MOI) (2011). Nepal Investment Guide. Author.

Ministry of Industry (MOI) (2016). Nepal Investment Guide. Author.

Ministry of Agriculture (MOA). (2014). Twenty Years Agriculture Development Strategy (2014-

34). Kathmandu: Author.

Ministry of Commerce (MOC). (1992). Trade Policy 1992.Government of Nepal. Author.

Ministry of Finance (MOF). (2011). Economic Survey 2010/011. Kathmandu: Author.

Ministry of Finance (MOF). (2016). Economic Survey 2015/2016. Kathmandu: Author.

National Planning Commission (NPC). (2002). Tenth plan. Kathmandu: Author.

National Planning Commission (NPC). (1995). Nepal Agricultural Perspective Plan. Kathmandu: Author.

National Planning Commission (NPC). (1998). The Ninth Plan. Kathmandu: Author.

National Planning Commission (NPC). (2017). Nepal's Sustainable Development Goals: Baseline Report June 2017. Kathmandu: Government of Nepal. Author.

National Planning Commission (NPC) (2016). 14th Thee Year Plan (2016/17-2018/19). Kathmandu: Author.

Organization for Economic Development and Cooperation (OECD) (2016). A New Rural Development Paradigm for the 21st Century: A Toolkit for Developing Countries. Author.

Rogers, E. M. \& Shoemaker, K. (1971). Communication of Innovation: A Cross-Cultural approach, (2nd ed.). London: Collar Macmillan Publisher.

Tang, K. (2011). Industrial-Organization-Transformation-Oriented Agricultural Modernization with Chinese Characteristics: From the Perspective of Industrial and Agricultural Interaction. International Journal of Business and Management, 6 (5), 211-216.

United Nations Development Programme (UNDP). (2015). Human Development Report 2015: Work for Human Development. New York: NY 10017, USA.

Trade and Export Promotion Centre (TEPC). (2016). Nepal Foreign Trade Statistics-2015/16. Lalitpur: Author.

United Nations (UN). (2015). Transforming our World: The 2030 Agenda for Sustainable Development. https://sustainabledevelopment.un.org/post2015/transformingourworld

Scotland, J. (2012). Exploring the Philosophical underpinning of Research: Relating Ontology and Epistemology to the Methodology and Methods of the Scientific, Interpretive and Critical Research Paradigm. English Language Teaching, 5 (9), 13-16.Author.

World Bank (WB). (2010). Enhancing agricultural innovation: how to go beyond the strengthening of research systems. Washington, DC: Author.

Village Profile (2015). Village level Profile of Lele Village Development Committee. Author.

Yesuf, M. \& G. Kohlin (2008). "Market imperfections and farm technology adoption application to the Peruvian Sierra." Review of Economic Studies, 60, 903-921. 